\title{
Consumer behavior in the disposal of Information Technology Equipment: characterization of the household flow
}

\author{
O comportamento do consumidor no descarte de Equipamentos da \\ Tecnologia da Informação: um estudo de caso da caracterização \\ do fluxo domiciliar
}

\author{
Luiz Phillipe Mota Pessanha1 (1), Gudelia Morales² \\ ${ }^{1}$ Centro Federal de Educação Tecnológica Celso Suckow da Fonseca - CEFET, Departamento de Engenharia de \\ Produção, Rio de Janeiro, RJ, Brasil. E-mail: luiz.pessanha@cefet-rj.br \\ ${ }^{2}$ Universidade Estadual do Norte Fluminense - UENF, Laboratório de Engenharia de Produção - LEPROD \\ Programa de Pós-graduação em Engenharia de Produção - PPGEP, Campos dos Goytacazes, RJ, Brasil. E-mail: \\ gudelia@uenf.br
}

How to cite: Pessanha, L. P. M., \& Morales, G. (2020). Consumer behavior in the disposal of Information Technology Equipment: characterization of the household flow. Gestão \& Produção, 27(3), e4313. https://doi.org/10.1590/0104-530X4313-20

\begin{abstract}
The management of Waste Electrical and Electronic Equipment (WEEE) or electronic waste (e-garbage or e-waste) has become a major concern for urban communities due to the large volumes of waste generated, from the end of the 20th century. In this context, this work seeks to gather information for the implementation of a Reverse Logistics system that is comprehensive and regular for WEEE in the city of Campos dos Goytacazes - RJ. The behavior of the consumer was analyzed using a version adapted and inspired by the AHP Method, regarding to the most relevant considerations when disposing of WEEE (cell phones, computers and tablets). The data needed for this work were collected through the application of a questionnaire with open and closed questions to a sample, random and representative of citizens, in the city under study. It was noticed that the results found would support the decisions to be taken in the design of an efficient management system for WEEE. It is also worth mentioning that this research was carried out under the current considerations of sustainability according to what determines the Brazilian legislation on Solid Waste and can be intended as a prototype to be adapted to the reality of other cities in the country.
\end{abstract}

Keywords: Sustainability; Electronic waste; AHP method.

Resumo: A gestão de Resíduos de Equipamentos Elétricos e Eletrônicos (REEE) ou lixo eletrônico (e-lixo ou e-waste) tem se tornado grande motivo de preocupação para as comunidades, governos e instituições de gestão e de regulação ambientais, devido aos grandes volumes de resíduos gerados, a partir do consumo, no final do século XX. Nesse contexto, esse trabalho busca levantar informações importantes para implantação de um sistema de Logística Reversa abrangente e regular para os REEE da Tecnologia da Informação no município de Campos dos Goytacazes - RJ. Foi analisado o comportamento do consumidor, utilizando uma versão adaptada e inspirada no Método AHP, com respeito as considerações mais relevantes no momento do descarte de REEE (celulares, computadores e tablets). Os dados deste trabalho

Received Sept. 11, 2017 - Accepted Mar. 28, 2018

Financial support: CAPES. 
foram levantados através da aplicação de questionários a uma amostra representativa no município em estudo. Constatou-se que os resultados encontrados apoiam as decisões tomadas no dimensionamento de um sistema de gestão eficiente dos REEE. Ressalta-se ainda que essa pesquisa aparece sob as considerações atuais de sustentabilidade segundo o que determina a legislação brasileira sobre Resíduos Sólidos e pode ser utilizada como protótipo para estudo em outras cidades do país.

Palavras-chave: Sustentabilidade; Lixo eletrônico; Método AHP.

\section{Introduction}

The competitive environment in which companies find themselves fosters the search for technological innovation aimed at ensuring market survival and better profit rates. In this sense, the rapid technological development embedded in new products, precisely with a wish, sometimes induced by media, of consumers in acquiring newly launched products, is leading to the environmental problem: the generation of more waste and its inadequate disposal, because products are discarded prematurely even before they lose their functionality (Pochampally et al., 2009; Victor \& Kumar, 2012).

This fact is more preponderant when we consider the sector of the electronics industry, which now clearly illustrates this production dynamics, consumption and generation of waste. This is mainly due to shortening the life cycle of products or Electronic Electrical Equipment - EEE, causing them to have planned or calculated obsolescence, aiming their quick replacement and, thus, turning the wheel of the consumer society (Silva, 2012); adding up the fact that they have very low recycling rates (Victor \& Kumar, 2012).

Waste Electrical and Electronic Equipment (WEEE) corresponds to EEE discarded by users and includes components, subsets and materials that are part of the product at the time of disposal (Tsydenova \& Bengtsson, 2011; Rodrigues, 2012). The increasing volume of generation of these wastes combined with their high-risk composition, due, in large part, to the heavy metals (such as mercury, cadmium and lead) required in their manufacture, until now, implicate to difficulties in their proper disposal and treatment (Echegaray \& Hansstein, 2017). It is worth mentioning that improper disposal of WEEE in landfills and controlled landfills endangers the soil and may even contaminate groundwater and river waters by releasing heavy metals.

As pointed out in the article by Cox et al. (2013), most of small electronics (such as cell phones, computers, etc.) are considered to have an expected life cycle of less than five years. In addition, these products are easily disposed before the end of their useful life, in order to remain in line with technological advances.

Due to the diversified composition, the management of the WEEE recycling chain becomes complex, for example, the collection and treatment activities of WEEE are costly and require good planning. Hence, it became important to formulate and implement specific legislation in order to equate the logistics required for recycling, which involves the environmentally safe collection, sorting, transportation and disposal of the same. For instance, it's used the extension of responsibility of producing and/or trading companies for the disposal of products manufactured and/or marketed.

Li et al. (2012) commented that developed countries have been leading the way in establishing formal systems for the treatment of WEEE since the early 1990s, starting with the European Union's granting of directives for the treatment of WEEE. In Brazil, Federal Law No. 12,305/2010 found the National Solid Waste Policy), which set up principles, objectives and directions for the integrated management of solid waste in 
the country (Article 1), sharing responsibilities among manufacturers, consumers and public authority responsible for urban cleaning (Item XVII, Art. 3). Rodrigues (2016) highlights the existence of a fourth stakeholder, represented by companies (or collector cooperatives) that manage recyclable waste.

The PNRS also talks about the obligation of consumers to adequately make available their solid waste for collection and return, whenever there is a municipal selective collection system, consequently an established Reverse Logistics system (ABDI, 2013).

Emerging LR systems in developing countries, such as Brazil, face problems such as loopholes in legislation, lack of economic incentives, low consumer awareness, products with no legal origination (sometimes called orphan EEE or gray market), and recyclable materials collectors who collect and allocate increasing amounts of WEEE with little preparation to deal with health, safety and environmental protection risks (Demajorovic et al., 2016; Echegaray \& Hansstein, 2017).

In the city of Campos, as in most Brazilian cities, there is still no Reverse Logistics system for WEEE, as it is already the case for agrochemical packaging, for example. The National Institute for the Processing of Empty Packaging (INPEV) is responsible for the management of the reverse logistics system for empty packaging of pesticides; created in compliance with Federal Law 9.974/2000 and Decree 4.074/2002 (INPEV, 2015). Likewise, in the same direction, there is a national program for collecting and disposing of waste tires, the Reciclanip Program, which activities comply the CONAMA Resolution 416/09, this program was created by tire manufacturers operating in Brazil. A management model for WEEE requires a diagnosis that regards the specific characteristics of the institutional and household information flows, equivalent to EEE production and disposal flows.

In particular, home flow has specific characteristics, such as diffuse generation given mainly by the EEE lifetime factor, in other words, predicting when and how the products will be disposed, in addition there are difficulties related to consumers' behavior and practice.

The lack of environmental concern of citizens and recycling channels in the city contributed to the inadequate disposal of EEE, demanding an urgent need to establish a WEEE management system that uses Reverse Logistics processes.

In this context, this work aims to identify and prioritize, in the consumer perceptions, the criteria that influence the proper disposal of cell phones, computers and tablets in Campos dos Goytacazes, a medium-sized town located in the north of the state of Rio de Janeiro with a population estimated at more than 490 thousand inhabitants, distributed a total of 150 neighborhoods, being the 6th most populous city in the state, with an average density of $115 \mathrm{hab} . / \mathrm{km}^{2}$ (IBGE, 2018), and with a high concentration of Universities in the municipality. It has been selected for the research, an accurate estimated sample in order to provide subsidies for the implementation of a Reverse Logistics model for WEEE in the city, which could be intended as a prototype to be adapted to other realities of the country.

The results of this research are intended to provide a basis for optimizing and supporting policy planning for WEEE that seeks to improve waste management systems by reinforcing the need for recycling industries and their supply chain. In addition, serve to monitor federal, state and municipal legislative implementation. Finally, as pointed Oteng-Ababio et al. (2016) when properly nourished, regulated and managed the WEEE recycling system can promote economic growth and job creation. 


\section{Reverse and closed cycle supply chain}

Environmental awareness has become an obligation for most companies within the traditional Supply Chain (CS) or direct CS (it means, the chain which includes all activities necessary for the production of new products from raw materials and their distribution to consumers) due the legislation and growth of the present environmental concern from users (Savaskan et al., 2004; Lambert \& Gupta, 2005).

Sustainable Supply Chain Management has been developed by manufacturing companies not only as a response to external pressures, as previously reported, but also as a strategic business vision, with the objective of obtaining better environmental and commercial results, such as reduction in manufacturing costs of products from reprocessing materials and components (Figueiró, 2010).

Reverse Logistics (LR) consists of a series of activities required to collect a product from the consumer. Leite (2005) presents two types of LR, the first called postconsumer LR that concerns itself with the reverse flow of discarded products at the end of its useful life. In the other hand, after-sales LR deals with products with little or no use, for example, for quality problems. The LR proposed by the PNRS is the postconsumption and applies to the discarded products after their use by the consumer.

For Pochampally et al. (2009), the reverse supply chain involves post-consumer LR operations in order to reprocess products both to recover their market value and to discard them appropriately. The combination of direct and reverse supply chains is called the Closed-Cycle Supply Chain (Pochampally et al., 2009), not considering the post-sale LR, as it is generically represented in Figure 1.

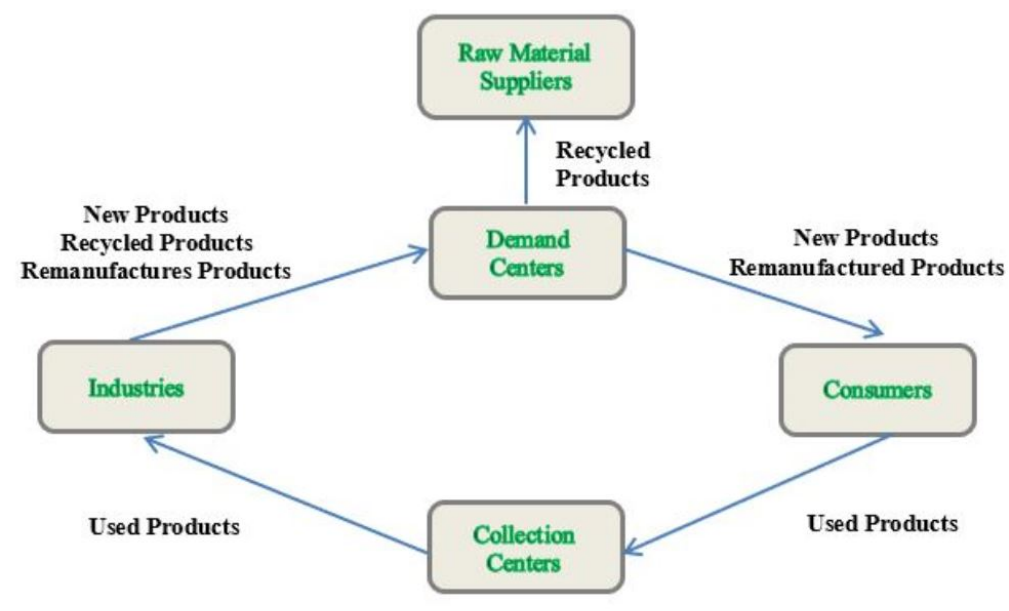

Figure 1. Generic representation of a Closed Cycle Supply Chain or Network. Adapted from Pochampally et al. (2009).

The Closed Cycle Supply Chain or Network has the application of most industries, including automotive, chemical, clothing, electronics, among others.

As it has been seen, the Closed Cycle Supply Chain or Network requires an expansion of direct supply chain management, emphasizing economic, ecological and social aspects in business practices, such as: social responsibility, green purchasing strategies, life cycle analysis of the product, substitution and reutilization of inputs, Reverse Logistics, correct disposal of waste, among others (Svensson, 2007). 


\section{Analytic hierarchy process - AHP method}

According to Saaty \& Vargas (1991) the Analytic Hierarchy Process - AHP is a systematic procedure used to represent hierarchically the elements or criteria of a problem. It rationally organizes the division of a problem into its smaller and smaller parts and then guides decision makers through a series of comparative trials in pairs (which is documented and can be reexamined) to express relative strength or intensity of the impact of the criteria in the hierarchy. These judgments are staggered verbally and range from equal to extreme importance. In general, a numerical scale, proposed by Saaty (2000), is used to represent the judgments, according to Table 1.

Table 1. The fundamental scale.

\begin{tabular}{ccc}
$\begin{array}{c}\text { Intensity of } \\
\text { importance }\end{array}$ & Definition & Explanation \\
\hline 1 & Equal importance & Two criteria contribute equally to the objective \\
\hline 3 & $\begin{array}{c}\text { Moderate importance of one } \\
\text { over another } \\
\text { Essential or strong } \\
\text { importance }\end{array}$ & $\begin{array}{c}\text { Experience and judgment strongly favor one } \\
\text { criterion over another }\end{array}$ \\
\hline 5 & Very strong importance & $\begin{array}{c}\text { An criterion is strongly favored and it } \\
\text { criterion over another } \\
\text { dominance demonstrated in practice }\end{array}$ \\
\hline 9 & Extreme importance & $\begin{array}{c}\text { The evidence favoring one criterion over } \\
\text { another is of tile highest possible order of } \\
\text { affirmation }\end{array}$ \\
\hline $2,4,6,8$ & $\begin{array}{c}\text { Intermediate values between } \\
\text { the two adjacent judgments }\end{array}$ & When compromise is needed \\
\hline
\end{tabular}

Source: Saaty (2000).

An important task in the decision-making process is to choose the factors that are relevant to that decision. In the AHP method we can organize these factors, once selected, into a hierarchical structure from a set of criteria, subcriteria (if any) and alternatives at successive levels, as shown in Figure 2. AHP is designed for situations in which ideas, feelings and emotions that affect decision-making are quantified to provide a numerical scale in order to determine certain priorities (Saaty, 1990; Taha, 2013).

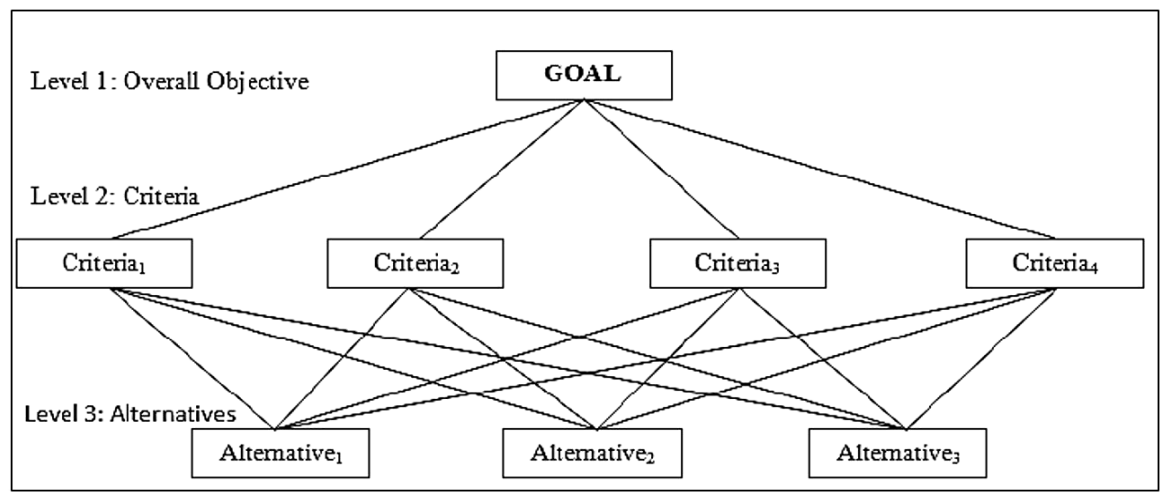

Figure 2. Structure of hierarchies. 
We will expose the following the systematic of the AHP method, according to Saaty (1990) and Taha (2013). The general structure of the AHP may include several hierarchies of criteria. Suppose we are dealing with $n$ criteria in a given hierarchy. Let's build the comparison matrix $\mathbf{A}$, pairwise, which quantifies the decision-maker judgment in terms of the relative importance of the different criteria. A pairwise comparison is done in such a way that the criterion on row $i(i=1,2, \ldots, n)$ is ranked in relation to all other criteria. Defining the element $(i, j)$ of $\mathbf{A}$ as $a_{i j}$, the AHP uses the numerical scale (according to Table 1) in which, for example, the input $a_{i j}=1$ means that criterion $i$ has equal importance with criterion $j ; a_{i j}=9$ indicates that $i$ is much more important than $j$; the interpretation is analogous to the other values on the scale.

Consistency in judgment requires that $a_{i j}=p$ automatically implies $a_{j i}=\frac{1}{p}$. Any matrix of positive entries with this property is called a reciprocal matrix. In addition, $\mathbf{A}$ is consistent when the following condition is satisfied: $a_{i j} a_{j k}=a_{i k}$, for all $i, j, k=1, \ldots, n$.

The principal diagonal of matrix A must have entries equal to 1 , since elements $a_{i i}$ classify a criterion in relation to itself.

It is important to emphasize that it is not common for all comparison matrices to be consistent, since the basis for building such matrices is the human judgment. Therefore, some reasonable degree of inconsistency is expected and tolerated.

To determine if a consistency level is acceptable, it was necessary to develop an index that quantifies the distance from the consistency condition of a comparison matrix $\mathbf{A}$. It is known that a consistent matrix produces a normalized matrix (weight matrices) in which all the columns are identical, such as Equation (1):

$$
\boldsymbol{N}=\left[\begin{array}{cccc}
w_{1} & w_{1} & \ldots & w_{1} \\
w_{2} & w_{2} & \ldots & w_{2} \\
\vdots & \vdots & \vdots & \vdots \\
w_{n} & w_{n} & \ldots & w_{n}
\end{array}\right]
$$

In the matrix $\mathbf{N}$ each element $w_{i j}$ is obtained by dividing the respective element $a_{i j}$ of the comparison matrix $\mathbf{A}$ by the sum of the entries of its column $j$.

With the normalized matrix, it's possible to calculate the PML's (Local Medium Priorities), obtained through the means of the matrix rows. These PML's represent the priority of each criterion within the hierarchical structure.

The original comparison matrix $\mathbf{A}$ can then be retrieved based on the inputs of matrix $\mathbf{N}$, dividing the elements of column $j$ by $w_{j}$, as shown in Equation (2):

$$
\boldsymbol{A}=\left[\begin{array}{cccc}
1 & w_{1} / w_{2} & \ldots & w_{1} / w_{n} \\
w_{2} / w_{l} & 1 & \ldots & w_{2} / w_{n} \\
\vdots & \vdots & \ldots & \vdots \\
w_{n} / w_{l} & w_{n} / w_{2} & \ldots & 1
\end{array}\right]
$$

By the given definition of A, we have Equation (3): 


$$
\left[\begin{array}{cccc}
1 & w_{1} / w_{2} & \ldots & w_{1} / w_{n} \\
w_{2} / w_{1} & 1 & \ldots & w_{2} / w_{n} \\
\vdots & \vdots & \ldots & \vdots \\
w_{n} / w_{l} & w_{n} / w_{2} & \ldots & 1
\end{array}\right]\left[\begin{array}{c}
w_{1} \\
w_{2} \\
\vdots \\
w_{n}
\end{array}\right]=n\left[\begin{array}{c}
w_{1} \\
w_{2} \\
\vdots \\
w_{n}
\end{array}\right]
$$

By multiplying the matrix A by the vector of local mean weights $\boldsymbol{w}=\left(w_{1}, w_{2}, \ldots, w_{n}\right)^{T}$, the result of this multiplication is $A w=n w$, which in Linear Algebra refers to the following definition: the vector $\boldsymbol{w}$ is the eigenvector of $\mathbf{A}$ and $n$ is the eigenvalue associated with the vector $w$.

Each row of matrix $\mathbf{A}$ is a constant multiple of the first row $\left(1, \frac{w_{1}}{w_{2}}, \ldots, \frac{w_{1}}{w_{n}}\right)$, why consider row $\quad i\left(\frac{w_{i}}{w_{1}}, \frac{w_{i}}{w_{2}}, \ldots, \frac{w_{i}}{w_{i-1}}, 1, \frac{w_{i}}{w_{i+1}}, \ldots, \frac{w_{i}}{w_{n}}\right)$ this can be written as $w_{i}\left(\frac{1}{w_{1}}, \frac{1}{w_{2}}, \ldots, \frac{1}{w_{i-1}}, \frac{1}{w_{i}}, \frac{1}{w_{i+1}}, \ldots, \frac{1}{w_{n}}\right)$ and multiplying $w_{i}$ for $w_{l} / w_{l}$, the result $\frac{w_{i}}{w_{I}}\left(\frac{w_{I}}{w_{I}}, \frac{w_{I}}{w_{2}}, \ldots, \frac{w_{I}}{w_{i-1}}, \frac{w_{I}}{w_{i}}, \frac{w_{I}}{w_{i+1}}, \ldots, \frac{w_{I}}{w_{n}}\right)$ a multiple of the first row of $\mathbf{A}$. Then the rank of matrix $\mathbf{A}$ is 1 . Thus, from Linear Algebra, $n-1$ eigenvalues are equal to 0 . The sum of the eigenvectors of a matrix is equal to its trace, it means, the sum of the elements of the principal diagonal. In this case, the trace of matrix $\mathbf{A}$ is equal to $n$, and $n$ is the largest eigenvalue or principal of $\mathbf{A}$.

The solution of $\boldsymbol{A} w=n w$ is composed by positive inputs and it is unique, except by a multiplicative constant. To make the vector $w$ unique, normalize its entries by dividing them by the sum of the elements of $w$.

In a general decision-making environment it is difficult to accurately identify the values of the ratio $w_{i} / w_{j}$, so it's only made their estimates. Estimates of these values

will be considered by a specialist who may make small errors of judgment. It is known that a small perturbation around a simple eigenvalue, as we have in $n$ when $\mathbf{A}$ is consistent, leads to a problem of eigenvalues of the form $A w=\lambda_{\max } w$ where $\lambda_{\max }$ is the principal eigenvalue of $\mathbf{A}$, where $\mathbf{A}$ may not be more consistent, but still reciprocal. The problem now is: to what extent does $w$ reflect the expert's real opinion?

Observe that we obtain $w$ by solving this problem, and then we form a matrix with the inputs $w_{i} / w_{j}$, we obtain an approximation for $\mathbf{A}$ by a consistent matrix.

An interesting result is that the inconsistency along the matrix can be captured by a single number $\lambda_{\max }-n$ that measures the deviation of the consistent approximation judgments.

Thus, there are two important theorems (Saaty \& Vargas, 1991):

Theorem 1: Be $\mathbf{A}_{n x n}$ a reciprocal matrix of positive real entries, $\mathbf{A}$ has a maximum eigenvector $\lambda_{\max } \geq n$.

Theorem 2: Let be $\mathbf{A}_{n x n}$. a reciprocal matrix of positive real entries. The matrix will be consistent if and only if $\lambda_{\max }=n$, that is, $A \boldsymbol{w}=n \boldsymbol{w}$. .

In the AHP method it is necessary to calculate the Consistency Ratio (CR), which refers to the evaluation of the inconsistency of the comparison matrix. As can be seen in Theorem 2, the closer $\lambda_{\max }$ is to $n$, the more consistent will be the matrix $\mathbf{A}$. The Consistency Ratio is calculated by the following Equation 4:

$$
C R=\frac{C I}{R I}
$$


where, $\mathrm{Cl}$ represents the Consistency Index given by $C I=\frac{\lambda_{\max }-n}{n-1}$ and RI, Random Consistency Index, calculated by $R I=\frac{1.98(n-2)}{n}$ (Taha, 2013). The Consistency Ratio will be accepted if $C R$ is less than or equal to $0.10(C R \leq 0.10)$.

As stated by Kim et al. (2013) the AHP method can be used as an important decision-making tool in WEEE management. Kim et al. (2013) use AHP to identify priority EEEs to be potentially regulated through WEEE management policies in Korea. Such identification is based on evaluation criteria that includeigh rate of waste generation, low cost of recycling, availability of technology, already established collection systems, among others. The opinions of experts, universities and industry secrs in the field of WEEE management and recycling were collected. The application of the above criteria, using AHP, indicate that among the top 10 target products for recycling, mobile phones appear at the top of the list.

Hernández et al. (2010) evaluate the use of AHP to measure the influence that Reverse Logistics practices have on corporate performance indicators, such as financial, customer perception regarding corporate image, internal processes, learning and growth. The research concludes that AHP is efficient when used to evaluate the influence of LR on performance indicators.

Other studies have used the AHP method for environmental management. In Hsu et al. (2008) the AHP was used to select the appropriate companies for the disposal of hospital waste. Wang et al. (2009) used this method to reduce the complexity of waste management systems in an attempt to select an appropriate solid waste landfill.

\section{Consumer behavior against WEEE}

Research appears to focus on a number of topics, such as: surveying the current status of WEEE Recycling; the study of the flow of materials, processing technology and consumer behavior towards recycling (Barr et al., 2005; Davis et al., 2006; González-Torre et al., 2003). In addition, the research methods and areas of focus for consumer recycling behavior can vary a lot. The work of Barr et al. (2001) addresses the perspective of consumer behavior regarding reuse and reduction of waste, using a combination of observation and regression analysis.

Rodrigues (2012) presented a study on the home flow generation and destination of WEEE in the city of São Paulo-SP. Through the application of questionnaires that sought to characterize, quantify and identify behaviors related to 26 types of EEE. The analysis of the data obtained in this research allowed us to estimate the total of equipment in use and out of use, besides discarded in the households, resulting in an amount of 71.8 million EEA. In this work it was also verified that WEEE are being discarded along with common solid waste, which exacerbates aspects such as inadequate fate to sanitary landfills, CFC gas release, soil risks, among others.

In Li et al. (2012) consumer recycling behaviors are investigated in a medium-sized city in China. Using questionnaires, the aim was to identify methods of consumption and the recycling and disposal channels of EEE. The results showed that villagers are influenced by the value of WEEE - money that a home can get when selling WEEE to a scrap dealer or a qualified treatment company - about $52 \%$ of residents sell WEEE to scrap dealers. In this research, more than half of the respondents rejected the cost of treatment of household electronic waste, considering two strategies: the cost of 
loading to discard the product and the inclusion of the cost of disposal in the price of the new product. Finally, mobile phones were found to have the highest per capita ownership, reaching 0.71 units per person.

Ylä-Mella et al. (2015) examines consumers' awareness and perception regarding the recycling and reuse of cell phones in the city of Oulu, Finland. The survey revealed that there is consumer awareness of the importance of a waste recovery system, however, such awareness doesn't translate into recycling behavior. As noted, $55 \%$ of respondents have two or more unused mobile phones in their homes.

Darby \& Obara (2005) evaluate consumer attitudes towards eliminating small WEEE, once problems arise in the application of Directive 2002/96/EU, European Union (EU) legislation, to these product groups. As Polák \& Drápalová (2012) point out, in the EU the legislation to promote the collection and recycling of WEEE has been in force since 2003. However, the current collection and recycling targets are considered ineffective when dealing with WEEE from small dimensions, with the case of cell phones.

In contrast to most studies that have focused on mature LR forms and systems in developed countries, such as the European Union (EU), this paper takes a consumer-driven approach to facilitating factors and barriers to discarding of WEEE in a medium-sized Brazilian city.

\section{Analytical model of research}

As presented in section 2.2, the AHP method structures the problem hierarchically. The Figure 3 below illustrates the structure of the proposed hierarchy for the case and the criteria considered.

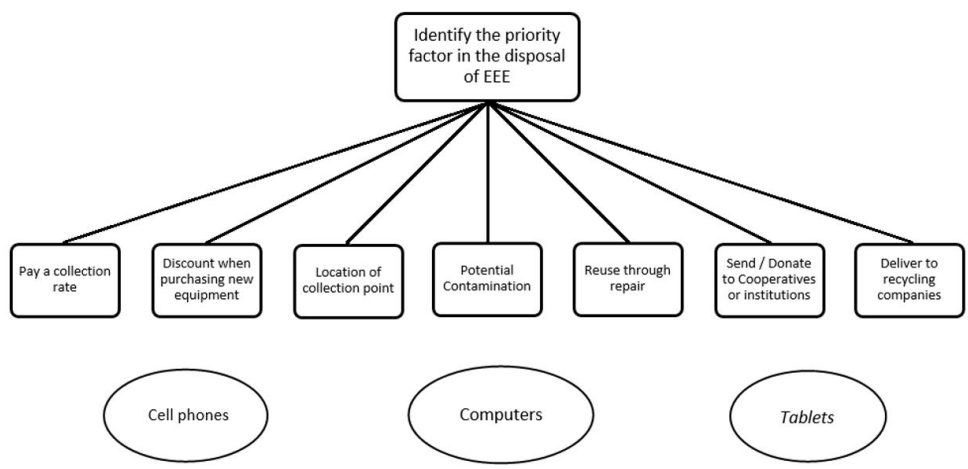

Figure 3. Structure of hierarchies.

These criteria were raised considering the research of Rodrigues (2016) that identifies and prioritizes variables that influence the Reverse Logistics of WEEE.

\section{Methodological procedures}

In order to collect the data needed for this research, the country's size and the nature of scientific research were considered. Then it was chosen by a geographical cut, treating the case of Campos dos Goytacazes in the state of Rio de Janeiro. A city with a population estimated by the IBGE (2018) of 490 thousand inhabitants, with 
specific cultural characteristics, considered as a university campus in the north of the State, and which coexists with a large supply and demand of consumer goods.

The instrument developed for this study was based on a questionnaire (Pessanha, 2017) established by the authors according to the research objective. In this questionnaire the following EEE were investigated: cell phones, computers (portable and personal) and tablets belonging to the Information Technology and Telecommunications Equipment category, specified in Directive 2012/19/EU.

This questionnaire was structured with questions that aim, primarily, to define the profile of the respondents. It was also identified the reason for the purchase and it was requested them to opt among the disposal possibilities (for example, "disposing in the common trash"). Finally, the behavior of the consumer at the time of disposal was evaluated, considering the level of importance attributed by him to the criteria listed (shown in Figure 3) in this research. It is worth emphasizing that the questions formulated for this questionnaire can be adapted to the reality of other Brazilian cities, considering the socioeconomic differences of each region.

Considering the participation of the consumer as an important link within a reverse chain and in order to support the decisions inherent in the implementation of a LR system, the consumer behavior was analyzed through the AHP method, adapted to the case, to identify and hierarchize the criteria and most relevant considerations at the time of disposal of each of the equipment considered (cell phones, computers and tablets).

Using the questionnaire, the degree of importance attributed by each consumer of each of the criteria analyzed for each type of EEE was identified. An importance scale of 5 points equivalent to the importance intensities 1, 3, 5, 7 and 9 (presented in Table 1) was used, which will later be converted to Saaty scale, using the Table 2 below, with a range interval of class $h=0.45$.

Table 2. Conversion Table for Saaty scale.

\begin{tabular}{cc}
\hline \multicolumn{2}{c}{ Conversion Scale for Saaty } \\
\hline Proposed Scale & Saaty Scale \\
\hline $0.00 \vdash 0.45$ & 1 \\
\hline $0.45 \vdash 0.90$ & 2 \\
\hline $0.90 \vdash 1.35$ & 3 \\
\hline $1.35 \vdash 1.80$ & 4 \\
\hline $1.80 \vdash 2.25$ & 5 \\
\hline $2.25 \vdash 2.70$ & 6 \\
\hline $2.70 \vdash 3.15$ & 7 \\
\hline $3.15 \vdash 3.60$ & 8 \\
\hline $3.60 \vdash 4.05$ & 9 \\
\hline
\end{tabular}

The details of this conversion and application of the AHP method can be followed in the next section. 


\section{Results and discussion}

The results of this research were obtained through the application of the questionnaires from July to December, in 2016. 328 valid questionnaires were applied, which $14 \%$ represent those applied online.

From the data tabulation, it was possible to construct Table 1 that shows the characteristics of the respondents.

As it can be observed, the majority of respondents are between 15 and 25 years old $(55.9 \%)$ and it is verified that the level of schooling in High School and higher education (college and Postgraduate) are the most frequent, $37.6 \%$ and $37.3 \%$, respectively.

When asked about the means of purchase of the investigated equipment (cell phone, computer and tablet), $53.5 \%$ of them have affirmed they had bought their equipment in a physical store, $24.4 \%$ bought through the internet and $22.1 \%$ bought both in physical store and through the Internet. These data collection were obtained considering the total number of respondents who answered this question $(n=271)$. The above mentioned collection becomes relevant when it is wanted to know the volume of sales of these products, a variable that has a strong connection with the accuracy of an estimation model of WEEE generation.

The option that the consumer ponders at the time when the EEE considered here is out of use has been investigated. The graphs below (Figures 4, 5 and 6) present the results. Through them, we can identify the number $n$ of validated responses to this questioning. In case of tablet the low number of answers can be justified because many respondents don't have this equipment and therefore didn't feel able to evaluate it.

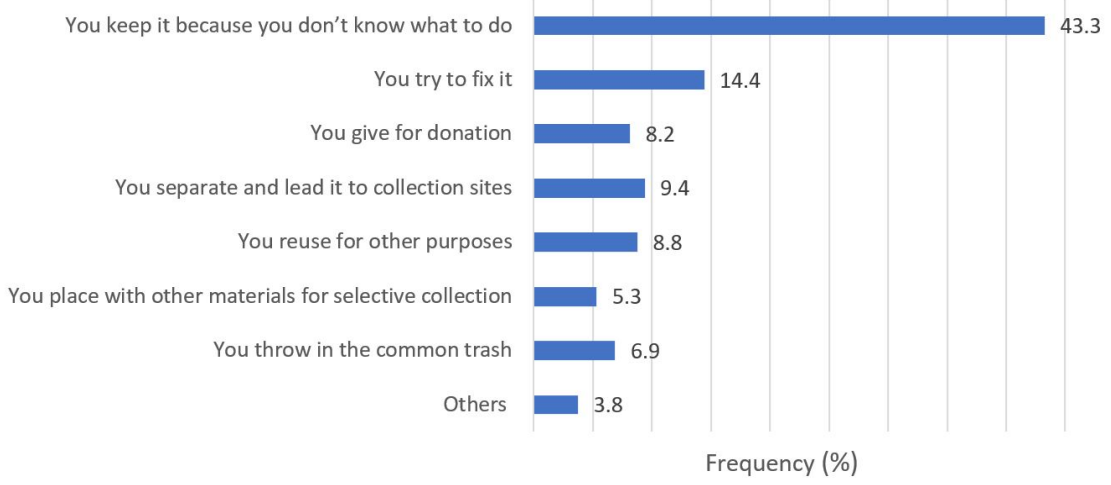

Figure 4. Graph of options considered for cell phones out of use $(n=319)$. 


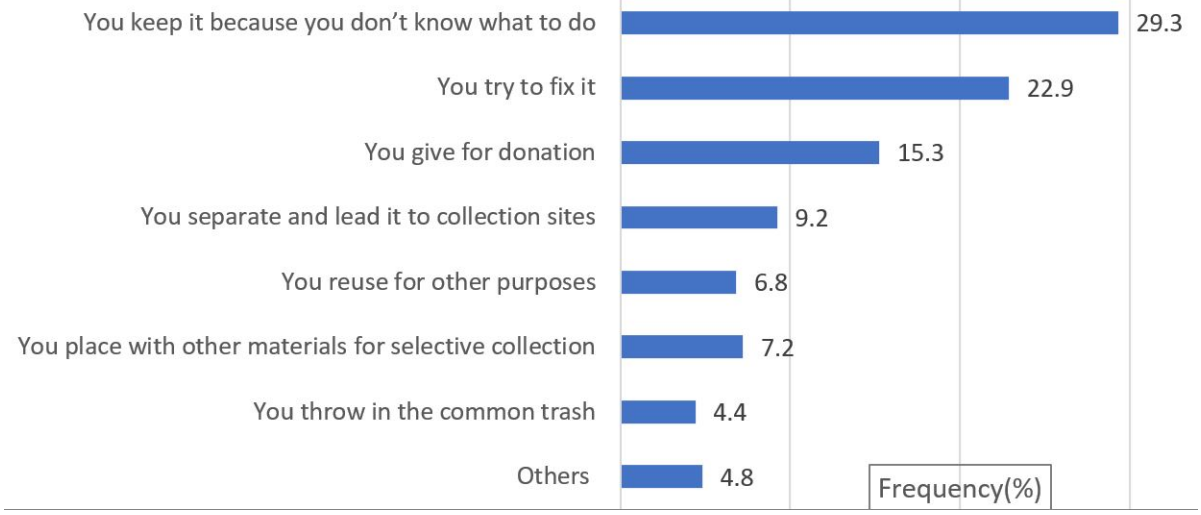

Figure 5. Graph of options considered for couters out of use $(n=249)$.

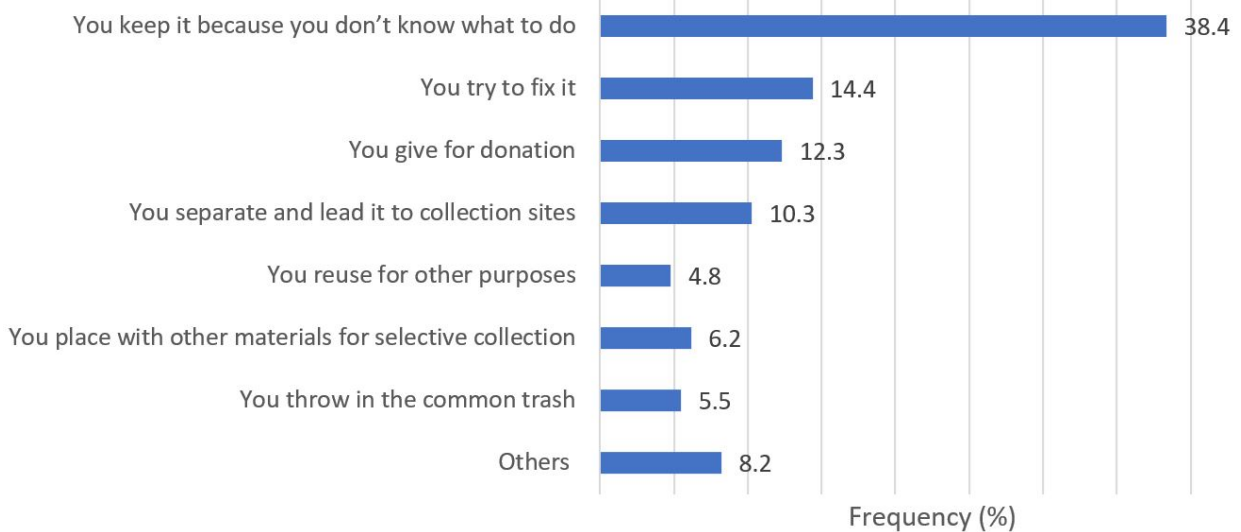

Figure 6. Graph of options considered for tablets out of use $(n=146)$.

As it can be observed, the most considered option by consumers for the three products is to store the equipment because they don't know what to do (43.3\% for cell phones, $29.3 \%$ for computers, and $38.4 \%$ for tablets). This conclusion demonstrates the predisposition of consumers to keep such equipment stored for several and particular reasons, such as affection to the good that had a high acquisition cost. Thus, for an accurate estimation of the WEEE generation, the importance of the stock variable investigation, defined as the sum of the equipment in use and stored by the consumers, is reinforced.

Those interviewed, who have chosen "Other" option, most indicate that they intend to sell the EEE when they are out of use.

When questioned about the possibility of free collection or delivery in specific places, of those out of use equipment, $96.9 \%$ of the respondents intend to deliver their equipment, which reinforces Dias et al. (2018) about the positive intention of the Brazilian population for recycling, despite few practical actions in this sense.

Another important result is that only $17.4 \%$ of respondents have heard about e-waste collection in Campos-RJ. 


\subsection{Analysis of consumer behavior}

Was aimed to know how consumers evaluated the most relevant criteria and considerations at the time of disposal of each of the equipment considered here (cell phones, computers and tablets), as hierarchized in Figure 3.

The Table 3 shows the general characterization of the respondents. From the data provided by the respondents regarding to the degree of importance of each of the 7 criteria considered here (Table 4), the geometric mean was calculated for each of the criteria and for each EEE considered, as shown in Table 5. The Tables 6, 7 and 8 show, for each of the equipment considered, matrix $\mathbf{A}$ of comparison for the 7 criteria formulated in this research. The Table 9 calculated the consistency ratio, less than 0.10 for all equipment, accepting matrix $\mathbf{A}$ as randomly satisfactory.

Table 3. General characteristics of respondents.

\begin{tabular}{ccccc}
\hline Education & \multicolumn{2}{c}{ Age } & Gender \\
\hline Don't read or write & $0.6 \%$ & From 15 to 25 years old: & $55.9 \%$ & Male: $42.8 \%$ \\
\hline Basic Education & $11.8 \%$ & From 26 to 35 years old: & $24.8 \%$ & Famale: $57.2 \%$ \\
\hline High School & $37.6 \%$ & From 36 to 45 years old: & $13.3 \%$ & \\
\hline College & $37.3 \%$ & From 46 to 55 years old: & $5.4 \%$ & \\
\hline Postgraduate & $12.7 \%$ & Over 56 years old: & $0.6 \%$ & \\
\hline
\end{tabular}

Table 4. Criteria considered.

\begin{tabular}{cc}
\hline Legend & Criteria \\
\hline C1 & Location of collection point \\
C2 & Receive by collection or discount when purchasing new equipment \\
\hline C3 & Pay a collection rate \\
C4 & Reuse through repair \\
\hline C5 & Potential Contamination \\
\hline C6 & Deliver to recycling companies \\
\hline C7 & Send/Donate to Cooperatives of collectors or institutions that practice reuse \\
\hline
\end{tabular}

Table 5. Geometric mean of the degrees of importance for the criteria.

\begin{tabular}{ccccccccc}
\hline \multicolumn{2}{c}{ Criteria } & C1 & C2 & C3 & C4 & C5 & C6 & C7 \\
\hline \multirow{3}{*}{ Geometric Mean } & Cell phones & 4.45 & 3.42 & 1.56 & 3.87 & 4.33 & 4.27 & 4.33 \\
\cline { 2 - 9 } & Computers & 4.41 & 3.23 & 1.67 & 3.89 & 4.41 & 4.30 & 4.27 \\
\cline { 2 - 9 } & Tablet & 4.29 & 3.09 & 1.61 & 3.76 & 4.45 & 4.26 & 4.22 \\
\hline
\end{tabular}

Table 6. Comparison Matrix for Cell phone.

\begin{tabular}{cccccccc}
\hline & C1 & C2 & C3 & C4 & C5 & C6 & C7 \\
\hline C1 & 1 & 3 & 7 & 2 & 1 & 1 & 1 \\
\hline C2 & $1 / 3$ & 1 & 5 & $1 / 2$ & $1 / 3$ & $1 / 2$ & $1 / 3$ \\
\hline C3 & $1 / 7$ & $1 / 5$ & 1 & $1 / 6$ & $1 / 7$ & $1 / 7$ & $1 / 7$ \\
\hline C4 & $1 / 2$ & 2 & 6 & 1 & $1 / 2$ & 1 & $1 / 2$ \\
\hline C5 & 1 & 3 & 7 & 2 & 1 & 1 & 1 \\
\hline C6 & 1 & 2 & 7 & 1 & & & 1 \\
\hline C7 & 1 & 3 & 7 & 2 & 1 & 1 & 1 \\
\hline
\end{tabular}


Table 7. Comparison Matrix for Computers.

\begin{tabular}{cccccccc}
\hline & C1 & C2 & C3 & C4 & C5 & C6 & C7 \\
\hline C1 & 1 & 3 & 7 & 2 & 1 & 1 & 1 \\
\hline C2 & $1 / 3$ & 1 & 4 & $1 / 2$ & $1 / 3$ & $1 / 3$ & $1 / 3$ \\
\hline C3 & $1 / 7$ & $1 / 4$ & 1 & $1 / 5$ & $1 / 7$ & $1 / 6$ & $1 / 6$ \\
\hline C4 & $1 / 2$ & 2 & 5 & 1 & $1 / 2$ & 1 & 1 \\
\hline C5 & 1 & 3 & 7 & 2 & 1 & 1 & 1 \\
\hline C6 & 1 & 3 & 6 & 1 & 1 & 1 & 1 \\
\hline C7 & 1 & 3 & 6 & 1 & 1 & 1 & 1 \\
\hline
\end{tabular}

Table 8. Comparison Matrix for Tablets.

\begin{tabular}{cccccccc}
\hline & C1 & C2 & C3 & C4 & C5 & C6 & C7 \\
\hline C1 & 1 & 3 & 6 & 2 & 1 & 1 & 1 \\
\hline C2 & $1 / 3$ & 1 & 4 & $1 / 2$ & $1 / 4$ & $1 / 3$ & $1 / 3$ \\
\hline C3 & $1 / 6$ & $1 / 4$ & 1 & $1 / 5$ & $1 / 7$ & $1 / 6$ & $1 / 6$ \\
\hline C4 & $1 / 2$ & 2 & 5 & 1 & $1 / 2$ & $1 / 2$ & $1 / 2$ \\
\hline C5 & 1 & 4 & 7 & 2 & 1 & 1 & 1 \\
\hline C6 & 1 & 3 & 6 & 2 & 1 & 1 & 1 \\
\hline C7 & 1 & 3 & 6 & 2 & 1 & 1 & 1 \\
\hline
\end{tabular}

Table 9. Calculation of Consistency Ratio.

\begin{tabular}{cccc}
\hline Comparison Matrix to: & $\boldsymbol{C I}$. & $\boldsymbol{R I}$. & $\boldsymbol{C R}$ \\
\hline Cell phone & 0.018 & 1.414 & 0.013 \\
\hline Computers & 0.015 & 1.414 & 0.011 \\
\hline Tablets & 0.013 & 1.414 & 0.009 \\
\hline
\end{tabular}

From these averages it was possible to obtain a parity judgment matrix by subtracting the means from a criterion $i$ with a criterion $j$ for $i, j=1,2, \ldots, 7$ building a comparison matrix, following: $a_{i j}=\bar{c}_{i}-\bar{c}_{j}$., where $\bar{c}_{i}$. is the average of the criterion $i \mathrm{e} \bar{c}_{j}$. is the average of the criterion $j$. Thus, we obtain $S\left(\bar{c}_{i}-\bar{c}_{j}\right) \operatorname{or} S\left(a_{i j}\right)$ defined as the judgment converted to Saaty scale for each $a_{i j}$, according to the conversion Table 2, proposed in section 5 .

Like this,

$a_{i j}=\left\{\begin{array}{l}S\left(\bar{c}_{i}-\bar{c}_{j}\right) \text {, when } \bar{c}_{i} \geq \bar{c}_{j} \\ \frac{1}{S\left(\bar{c}_{j}-\bar{c}_{i}\right)}, \text { when } \bar{c}_{i}<\bar{c}_{j}\end{array}\right.$

For example, the element $a_{12}=\bar{c}_{1}-\bar{c}_{2}=4.45-3.42=1.03$.nverted to $S\left(a_{12}\right)=3$. using conversion from Table 2 . The comparison matces presented in the following tables were obtain on this calculation logic.

With the comparison matrices it was possible to obtain the normalized matrices, as described in section 3. From these it is possible to find the Local Medium Priorities PML's and to rank the criteria, as can be observed in the graph of Figure 7. 


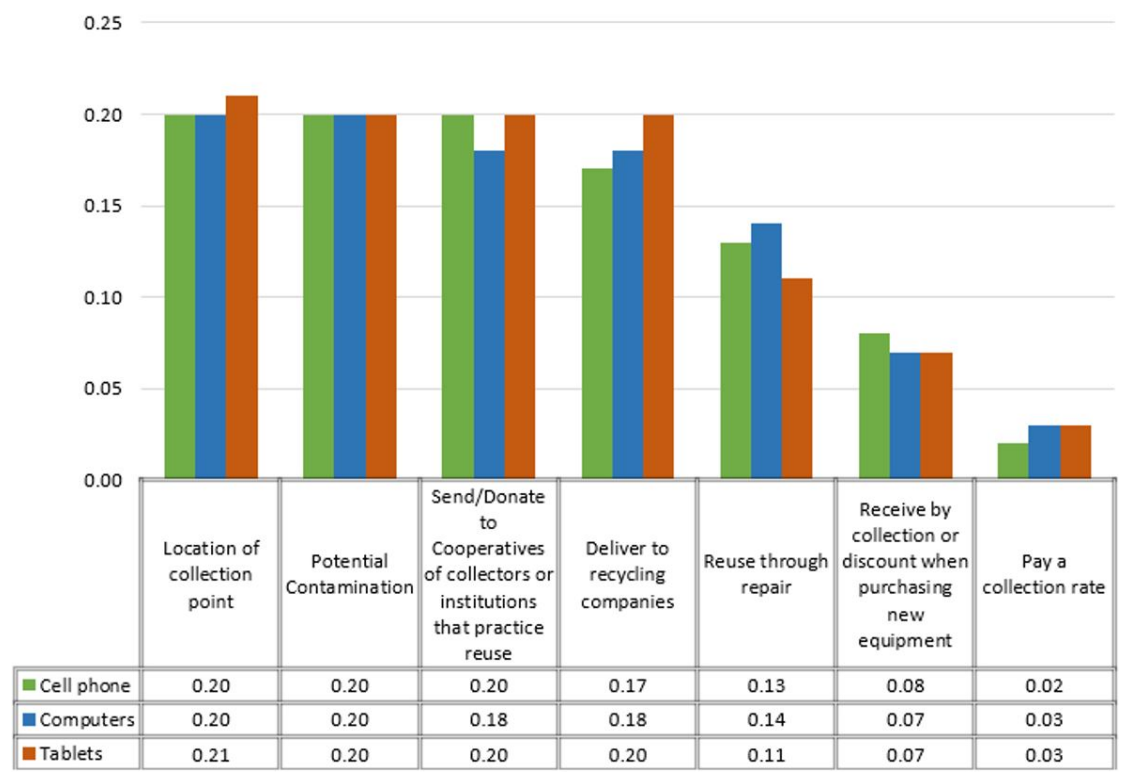

Figure 7. Graph of the criteria x PML's.

As can be observed, when we consider a criterion and its PML's for each EEE, the values are very close. This fact was identified during the application of the questionnaires through reports from the interviewees about perceiving the same degree of importance for the three EEE when evaluating each of the criteria.

The criteria Location of Collection Point, Potential of contamination of the EEE and the Sending or donation to institutions, all with $P M L=0.20$, appear as priority when it is necessary to discard cell phones.

For computers, the priority criteria are Collection Point Location and Potential Contamination, both with $P M L=0.20$. For tablets, the location of the collection point is a priority criterion with $P M L=0.21$.

The criteria Paying a collection rate obtained lower priority in the judgment of consumers, however a strategy adopted in Reverse Logistics systems is to embed in the purchase of the product a fee to finance the costs involved with the reverse flow of these products through the supply chain, such as can be seen in the LR model proposed by Demajorovic et al. (2016).

Redicted by the AHP method, it is necessary to calculate the Consistency Ratio for each comparison matrix, according to the following table:

The Consistency Ratio for the three matrices was less than 0.10 , which shows consistency in the judgments.

\section{Conclusions}

This research aimed to gather relevant information about the household flow of WEEE, considering that the consumer is an important link within the reverse chain. Consumer studies indicate that most of them are concerned about the correct disposal of EEE, but few know what to do with this material, either for lack of information or for the absence of appropriate disposal sites, as is the case for the city under study and in most of Brazilian cities. 
As pointed out, the consumers interviewed here tend to save the EEE because they do not know what to do with them when they fall into disuse and $96.9 \%$ of those interviewed intend to deliver their equipment, reinforcing the need for collection sites for WEEE that ensure, even, the flow of the material received, completing the activities of an efficient Reverse Logistics system.

In this same direction, the consumer behavior was analyzed at the time of disposal, seeking to know their priorities and support the decisions that involve a reverse logistics system for WEEE. It was identified that in the consumer's perception that the EEE collection site is an important criterion in the disposal of this type of waste.

It is worth highlighting the environmental benefits of the proper disposal of WEEE, which includes keeping groundwater contamination free by heavy metals, including ensuring soil quality for agriculture. In addition, economic opportunities can be created, such as urban mining.

As pointed out, consumers are willing to deliver their EEE when there is an appropriate option for disposing of them. One of the strategies that can be adopted by the public power, in partnership with companies producing and marketing, is to collect this waste and send it to companies located in Brazil. Such collection can be done by recycling cooperatives and municipal waste pickers who appear within the reverse supply chain as suppliers of LR services to producing companies. It is also worth noting that the generation potential in the city doesn't seem to be viable for a recycling industry in the region, which strengthens the participation of cooperatives, already existing in the city, within the LR system.

\section{References}

Agência Brasileira de Desenvolvimento Industrial - ABDI. (2013). Reverse logistics of electrical and electronic equipment: technical and economic feasibility analysis. Brasilia: Inventta.

Barr, S., Gilg, A., \& Ford, N. (2001). Differences between household waste reduction, reuse and recycling behavior: a study of reported behaviors, intentions and explanatory variables. Environmental \& Waste Management, 4, 1-14.

Barr, S., Gilg, A., \& Ford, N. (2005). Defining the multi-dimensional aspects of household waste management: A study of reported behavior in Devon. Resources, Conservation and Recycling, 45(2), 172-192. http://dx.doi.org/10.1016/j.resconrec.2004.12.007.

Cox, J., Griffith, S., Giorgi, S., \& King, G. (2013). Consumer understanding of product lifetimes. Resources, Conservation and Recycling, 79, 21-29. http://dx.doi.org/10.1016/j.resconrec.2013.05.003.

Darby, L., \& Obara, L. (2005). Household recycling behavior and atitudes towards the disposal of small electrical and electronic equipment. Resources, Conservation and Recycling, 44(1), 17-35. http://dx.doi.org/10.1016/j.resconrec.2004.09.002.

Davis, G., Phillips, P. S., Read, A. D., \& lida, Y. (2006). Demonstrating the need for the development of internal research capacity: understanding recycling participation using the Theory of Planned Behavior in West Oxfordshire, UK. Resources, Conservation and Recycling, 46(2), 115-127. http://dx.doi.org/10.1016/j.resconrec.2005.07.001.

Demajorovic, J., Augusto, E. E. F., \& Souza, M. T. S. (2016). Reverse logistics of WEEE in developing countries: challenges and perspectives for the Brazilian model. Ambiente \& Sociedade, 19(2), 117-138. http://dx.doi.org/10.1590/1809-4422ASOC141545V1922016.

Dias, P., Machado, A., Huda, N., \& Bernardes, A. M. (2018). Waste electrical and electronic equipment (WEEE) management: a study on the Brazilian recycling routes. Journal of Cleaner Production, 174, 7-16. http://dx.doi.org/10.1016/j.jclepro.2017.10.219. 
Echegaray, F., \& Hansstein, F. V. (2017). Assessing the intention-behavior gap in electronic waste recycling: the case of Brazil. Journal of Cleaner Production, 142, 180-190. http://dx.doi.org/10.1016/j.jclepro.2016.05.064.

Figueiró, P. S. (2010). A logística reversa de pós-consumo vista sob duas perspectivas na cadeia de suprimentos (Dissertação de mestrado). Universidade Federal do Rio Grande do Sul, Porto Alegre.

González-Torre, P. L., Adenso-Díaz, B., \& Ruiz-Torres, A. (2003). Comparative factors regarding recycling collection systems in regions of the USA and Europe. Journal of Environmental Management, 69(2), 129-138. http://dx.doi.org/10.1016/S03014797(03)00109-9. PMid:14550655.

Hernández, C. T., Marins, F. A. S., Rocha, P., \& Duran, J. A. R. (2010). Using AHP and ANP to evaluate the relation between reverse logistics and corporate performance in Brazilian industry. Brazilian Journal of Operations \& Production Management, 7(2), 47-62.

Hsu, P. F., Wu, C. R., \& Li, Y. T. (2008). Selection of infectious medical waste disposal firms by using the analytic hierarchy process and sensitivity analysis. Waste Management, 28(8), 1386-1394. http://dx.doi.org/10.1016/j.wasman.2007.05.016. PMid:17689065.

Instituto Brasileiro de Geografia e Estatística - IBGE. (2018). Campos dos Goytacazes. Retrieved in 2018, March 20, from https://cidades.ibge.gov.br/brasil/rj/campos-dosgoytacazes/panorama

Instituto Nacional de Processamento de Embalagens Vazias - INPEV. (2015). Logística reversa. São Paulo. Retrieved in 2016, March 20, from http://www.inpev.org.br/logisticareversa/logistica-reversa-das-packages

Kim, M., Jang, Y., \& Lee, S. (2013). Application of Delphi-AHP methods to select the priorities of WEEE for recycling in a waste management decision-making tool. Journal of Environmental Management, 128, 941-948. http://dx.doi.org/10.1016/j.jenvman.2013.06.049. PMid:23892135.

Lambert, A. J. D., \& Gupta, S. M. (2005). Disassembly modeling for assembly, maintenance, reuse and recycling. Boca Raton: CRC Press.

Leite, P. R. (2005). Reverse logistics: environment and competitiveness. São Paulo: Prentice Hall.

Li, J., Liu, L., Ren, J., Duan, H., \& Zheng, L. (2012). Behavior of urban residents toward the discarding of waste electrical and electronic equipment: a case study in Baoding, China. Waste Management \& Research, 30(11), 1187-1197. http://dx.doi.org/10.1177/0734242X12456728. PMid:22851535.

Oteng-Ababio, M., Owusu, G., \& Chama, M. (2016). Intelligent enterprise: wasting, valuing and re-valuing waste electrical and electronic equipment. The Geographical Journal, 182(3), 265-275. http://dx.doi.org/10.1111/geoj.12140.

Pessanha, L. P. M. (2017). Análise do comportamento do consumidor no descarte de equipamentos da tecnologia da informação e estimativa do potencial de geração: um estudo de caso em Campos - RJ (Dissertação de mestrado). Universidade Estadual do Norte Fluminense Darcy Ribeiro, Campos dos Goytacazes.

Pochampally, K., Nukala, S., \& Gupta, S. M. (2009). Strategic planning models for reverse in closed-loop supply chain. Boca Raton: CRC Press

Polák, M., \& Drápalová, L. (2012). Estimation of end of life mobile phones generation: the case study of the Czech Republic. Waste Management, 32(8), 1583-1591. http://dx.doi.org/10.1016/j.wasman.2012.03.028. PMid:22552041.

Rodrigues, A. C. (2012). Fluxo domiciliar de geração e destinação de resíduos de equipamentos elétricos e eletrônicos no município de São Paulo/SP: caracterização e subsídios para políticas públicas (Tese de doutorado). Universidade de São Paulo, São Paulo. 
Rodrigues, J. T. M. (2016). Seleção de variáveis para prever a demanda de resíduos de equipamentos eletroeletrônicos no contexto da logística reversa (Tese de doutorado). Universidade Federal do Rio Grande do Sul, Porto Alegre.

Saaty, T. L. (1990). How to make a decision: the analytic hierarchy process. European Journal Of Operational Research, North-holland, 48(1), 9-26. http://dx.doi.org/10.1016/03772217(90)90057-I.

Saaty, T. L. (2000). Decision making for leaders (3rd ed.). Pittsburgh: RWS Publications.

Saaty, T. L., \& Vargas, L. G. (1991). Analytical planning: the organization of systems (4th ed.). Pittsburgh: RWS Publications.

Savaskan, R. C., Bhattacharya, S., \& Van Wassenhove, L. N. (2004). Clossed-loop supply chain models with product remanufacturing. Management Science, 50(2), 239-252. http://dx.doi.org/10.1287/mnsc.1030.0186.

Silva, M. B. O. (2012). Programmed obsolescence and theory of decline versus the right to development and consumption (sustainable). Veredas do Direito, 9(17), 181-196.

Svensson, G. (2007). Aspects of sustainable supply chain management (SSCM): conceptual framework and empirical example. Supply Chain Management, 12(4), 262-266. http://dx.doi.org/10.1108/13598540710759781.

Taha, A. H. (2013). Operational research (8th ed., p. 363). Boston: Pearson.

Tsydenova, O., \& Bengtsson, M. (2011). Chemical hazards associated with treatment of waste electrical and electronic equipment. Waste Management, 31(1), 45-58. http://dx.doi.org/10.1016/j.wasman.2010.08.014. PMid:20869229.

Victor, S. P., \& Kumar, S. S. (2012). Planned obsolescence: roadway to increasing e-waste in indian government sector. International Journal of Soft Computing and Engineering, 2(3), 554-559.

Wang, G., Qin, L., Li, G., \& Chen, L. (2009). Landfill site selection using spatial information Technologies and AHP: a case study in Beijing, China. Journal of Environmental Management, 90(8), 2414-2421. http://dx.doi.org/10.1016/j.jenvman.2008.12.008. PMid:19375842.

Ylä-Mella, J., Keiski, R. L., \& Pongrácz, E. (2015). Electronic waste recovery in Finland: consumers' perceptions towards recycling and re-use of mobile phones. Waste Management, 45, 374-384. http://dx.doi.org/10.1016/j.wasman.2015.02.031. PMid:25797074. 